\title{
Upaya pemberantasan kutu rambut santri, pelatihan produksi sampo antiketombe dan wirausaha barbershop pesantren.
}

\author{
Viddy Agustian Rosyidi1 ${ }^{*}$, Ika Rahmawati Sutejo ${ }^{2}$ \\ ${ }^{1}$ Bagian Farmasetika, Fakultas Farmasi, Universitas Jember, Jember, Indonesia. \\ 2 Departemen Biokimia, Fakultas Kedokteran, Universitas Jember, Jember, Indonesia.
}

DOI: https://doi.org/10.29303/indra.v2i1.48

\section{Article Info}

Received : 31-07-2020

Revised : 19-10-2020

Accepted: 29-04-2021

\begin{abstract}
Head lice, dandruff and other scalp diseases are still one of the main problems of the students at the Nurul Qarnain boarding school. Factors that influence the development of disease are poor personal hygiene due to the students' lack of understanding of this disease. Anti-dandruff shampoo, is expensive and is insufficient to treat head lice problem among students. Furthermore, the absence of professional barbers in the boarding school environment is also one of the factors that triggered this problem. The results of this activity are increased knowledge of students about hair health from $58.8 \%$ to $98.24 \%$ and the ability and skills of students to make anti-dandruff shampoo and hair cutting. This is expected to increase awareness and ability to care for hair and provide added value to the economy.
\end{abstract}

Keywords: anti-dandruff, shampoo, barbershop, boarding school

Citation: Rosyidi, V.A., \& Sutejo, I.R. (2021). Upaya Pemberantasan Kutu Rambut Santri, Pelatihan Produksi Sampo Antiketombe dan Wirausaha Barbershop. INDRA Jurnal Pengabdian kepada Masyarakat, 2(1), 22-26. doi: https://doi.org/10.29303/indra.v2i1.48

\section{Pendahuluan}

Pondok pesantren (Ponpes) Nurul Qarnain yang pada awalnya bernama Pondok Pesantren Darul Ulum merupakan ponpes terbesar di wilayah utara kabupaten Jember (Budi, 2019). Berdiri di atas tanah seluas 3 hektar di Kecamatan Sukowono yang berjarak $23 \mathrm{~km}$ dari pusat Kabupaten Jember. Terdapat 32 kamar asrama yang menampung 1415 santri menetap. Santri yang menetap adalah santri tingkat madrasah tsanawiyah (MTs) dan aliyah (MA). Yayasan ponpes menyelenggarakan pendidikan formal dan nonformal yang lengkap, mulai PAUD sampai dengan madrasah aliyah, sehingga jumlah seluruh santri yang melakukan kegiatan di lingkungan ponpes mencapai 1700 orang. Ponpes mempunyai fasilitas yang lengkap. Untuk kegiatan MCK terdapat 58 unit kamar mandi dan 1 tandon air permanen penampung air dalam jumlah berlimpah untuk kebutuhan seluruh warga ponpes. Air wudhu santri dialirkan melalui pipa-pipa paralon ke tempat wudhu berupa deretan pancuran. Untuk kegiatan usaha mandiri, ponpes memiliki fasilitas 1 ruang tempat pelatihan, 2 koperasi dan beberapa usaha bidang pertanian serta peternakan.

Beberapa aspek yang dibutuhkan pesantren berkaitan dengan bidang kesehatan dan kewirausahaan diantaranya adalah potong rambut yang direspon sangat positif oleh semua anggota pesantren karena dianggap ketarampilan yang sangat dibutuhkan baik oleh santri maupun masyarakat (Haryono et al, 2016). Terdapat beberapa permasalahan yang dialami santri, yaitu: kutu rambut, ketombe dan penyakit kulit kepala lain dengan tingkat keparahan beraneka ragam, mulai dari gatal ringan sampai berat. Kutu rambut merupakan parasit yang menyebar luas di seluruh 
dunia (Rassami \& Soonwera, 2011). Ketombe menyebabkan rasa gatal yang sangat mengganggu pada kulit kepala dan lebih banyak menyerang pria (Polutri, 2013). Bila terjadi komplikasi, lesi dapat timbul infeksi bernanah.

Faktor yang mempengaruhi perkembangan kutu rambut dan ketombe adalah personal hygiene yang jelek, meliputi frekuensi cuci rambut yang jarang, tidak memakai sampo, terlambat mencukur rambut dan membiarkannya menjadi panjang, memakai handuk bergantian, tidak memperhatikan kebersihan alas tidur, dan tidur berdempetan (Rassami \& Soonwera, 2011). Personal hygiene yang bururk merupakan akibat ketidakfahaman bagaimana berperilaku sehat untuk menghindari penyakit ini. Prevalensi kutu rambut di suatu pesantren di Yogyakarta dengan personal hygiene yang jelek mencapai 71,3\%, (Alatas et al., 2013). Hal ini menunjukkan personal hygiene berperan sangat penting pada penyakit ini. Penyakit ini dirasa sangat mengganggu kegiatan belajar santri, gatal dapat mengganggu, tidur tiudak nyenyak dan menyebabkan mengantuk di siang hari, sehingga santri tidak menerima pelajaran dengan baik.

Salah satu bahan penting yang diperlukan santri untuk pencegahan maupun pengobatan penyakit Kutu rambut, ketombe dan penyakit kulit kepala lain adalah sampo. Penggunaan sampo antiketombe dan antikutu dengan bahan aktif herbal terbukti efektif mematikan kutu rambut sampai dengan 100\% (Surani dan Putriana, 2017). Harga sampo antiketombe rambut ini relatif mahal dibanding sampo biasa. Diperlukan upaya mengadakan sampo dengan harga murah melalui produksi sendiri oleh santri. Selain memenuhi kebutuhan sendiri, sampo ini dapat didistribusikan ke luar pondok melalui usaha koperasi yang sudah dimiliki ponpes.

Beberapa santri yang menderita penyakit tersebut mengatakan mereka terlambat mencukur rambut/membiarkan rambutnya menjadi panjang karena tidak ada fasilitas cukur rambut di lingkungan pondok, sedangkan tarif salon cukur rambut di luar pondok mahal. Diperlukan pelatihan teknik mencukur rambut secara profesional yang bisa dimanfaatkan oleh santri untuk membuat salon cukur rambut di lingkungan pesantren, santri yang telah dilatih teknik mencukur rambut bisa membuka salon di lingkungan pondok, memotong rambut santri lain dengan biaya murah, maupun menjadi salah satu bekal santri membuka usaha saat sudah lulus dari pondok.

\section{Metode}

Kegiatan yang dilaksanakan selama kegiatan pengabdian diawali dengan sosialisasi kepada pengasuh dan perwakilan santri. Kegiatan ini menciptakan komunikasi timbal balik antara tim pengusul dan mitra, mengenalkan program, serta memahami karakteristik mitra. Kegiatan inti berikutnya berupa transfer pengetahuan dan kegiatan pelatihan serta pendampingan. Adapun langkah berikutnya yang dilakukan untuk melaksanakan program pengabdian ini adalah penyusunan materi penyuluhan penyakit dan pencegahannya, serta materi pelatihan pembuatan sampo antiketombe dan penyakit kulit kepala lain. Materi yang akan disampaikan kepada mitra harus dipersiapkan dengan baik. Materi penyuluhan yang diberikan adalah mengenai seluk beluk penyakit kutu rambut, ketombe dan penyakit kulit kepala lain dan pencegahannya, terutama mengenai personal higiene. Materi lain yang harus dipersiapkan adalah materi pelatihan pembuatan sampo antikutu rambut dan antiketombe. Rincian bahan, alat dan metode pembuatan dikemas dengan kata-kata sederhana dan mudah dipahami oleh peserta pelatihan.

Tahapan berikutnya adalah pengumpulan data kasus penyakit kutu rambut, ketombe dan penyakit kulit kepala lain santri menurut tingkat keparahannya. Data jumlah penyakit ini dibutuhkan untuk menentukan berapa jumlah santri yang memerlukan terapi atau yang hanya memerlukan pencegahan saja. Data ini juga dibutuhkan untuk evaluasi keberhasilan program di tahap akhir nanti.

Kegiatan berikutnya yaitu penyuluhan mengenai penyakit kutu rambut, ketombe dan penyakit kulit kepala lain \& faktor yang mempengaruhi perkembangan penyakit ini, terutama personal hygiene untuk pencegahannya. Kegitan pengobatan juga dilakukan terhadap santri yang menderita penyakit kutu rambut, ketombe dan penyakit kulit kepala lain.

Pelatihan dan pendampingan membuat sampo antiketombe diawali dengan penyiapan bahan-bahan dan peralatan yang dibutuhkan. Mitra menjadi pihak utama dalam proses produksi sampo tersebut. Pelatihan teknik mencukur rambut yang diberikan oleh tenaga profesional sebanyak dua kali pertemuan. Pada pertemuan pertama santri diberikan pelatihan teknik cukur rambut, kemudian santri yang telah dilatih diberi kesempatan untuk mengaplikasikan keterampilan yang mereka dapatkan dari pelatihan. Pada pertemuan kedua, santri melakukan evaluasi kemampuan mereka bersama pelatih, santri melakukan praktek cukur rambut dibawah pengawasan pelatih, dilakukan diskusi \& penyempurnaan teknik cukur rambut yang sudah dikuasai santri. Tim pengusul program memberikan bantuan alat dan bahan untuk pendirian salon. Mitra menyedikan tempat dan santri yang telah dilatih teknik mencukur rambut akan berperan sebagai penyedia jasa. 


\section{Hasil dan Pembahasan}

\section{A. Penanganan kutu rambut, ketombe dan penyakit kulit kepala lain}

Materi yang akan disampaikan kepada mitra harus dipersiapkan dengan baik. Materi penyuluhan yang diberikan mengenai seluk beluk ketombe dan kutu rambut serta pencegahannya, terutama mengenai personal higiene. Materi lain yang dipersiapkan adalah materi pelatihan pembuatan sampo antiketombe dengan bahan aktif asam salisilat 3\%. Rincian bahan, alat dan metode pembuatan dikemas dengan kata-kata sederhana dan mudah dipahami oleh peserta pelatihan. Data jumlah penyakit ini dibutuhkan untuk menentukan berapa jumlah santri yang memerlukan terapi kutu rambut. Data ini juga dibutuhkan untuk evaluasi keberhasilan program di tahap akhir nanti. Pengumpulan data membutuhkan waktu 1 minggu karena jumlah santri keseluruhan lebih dari 1000 orang. Kegiatan ini dilakukan pada tanggal 12-16 September 2019. Metode pelaksanaan kegiatan ini, tim pengusul melakukan pendataan santri penderita satu persatu dengan memberikan daftar isian untuk identifikasi penyakit. Tim menanyakan apakah ada santri dengan keluhan gatal rambut, melakukan anamnesis dan pemeriksaan lebih lanjut dan identifikasi kasus. Hasil anamnesis menun jukkan bahwa $90 \%$ santri perempuan mengalami masalah kutu rambut.

Pengetahuan santri tentang kutu rambut dan ketombe diidentifikasi sebelum dan setelah adanya kegiatan penyuluhan untuk mengetahui sejauh mana peningkatan pengetahuan santri setelah mendapatkan materi penyuluhan. Hasil evaluasi tersebut akan menunjukkan efektifitas metode penyuluhan terhadap pemahaman santri tentang pencegahan dan penanganan kutu rambut dan ketombe. Hasil pretest menunjukkan bahwa pengetahuan santri tentang kesehatan rambut terkait kkutu rambut dan ketombe adalah 58,8\% sedangkan hasil posttest menunjukkan pengetahuan santri menjadi $98,24 \%$. Hasil evaluasi tersebut menunjukkan peningkatan pemahaman yang cukup signifikan oleh santri setelah dilakukan penyuluhan yang berarti materi penyuluhan telah disampaikan secara efektif.

Sebelum mengobati kutu rambut dengan menggunakan obat-obatan, sebaiknya lakukan penanganan dengan cara sederhana terlebih dahulu dengan mendeteksi keberadaan kutu rambut dengan memakai sisir serit. Metode penyisiran yang sebaiknya digunakan adalah dengan cara basah. Ulangi penyisiran di hari kelima, kesembilan, ketiga belas, dan ketujuhbelas. Jika pembersihan menggunakan sisir rambut belum berhasil, digunakan obat antiparasit. Salah satunya adalah permethrin. Antiparasit ini tidak dapat langsung membunuh telur kutu. Oleh karenanya, diperlukan setidaknya dua kali pemakaian untuk memastikan kutu benar-benar mati hingga ke telurnya. Jika tidak berhasil, dokter akan meresepkan obat malathion, benzyl alcohol. atau lindane dalam bentuk sampo (Surani dan Putriana, 2017).

Tujuan dari pengobatan ketombe adalah memperlambat reproduksi sel kulit kepala, atau menghambat perkembangan jamur yang menyebabkan munculnya ketombe. Ada banyak pilihan sampo antiketombe yang dibedakan oleh kandungannya, yaitu 1) Zinc pyrithione. Zat ini berfungsi membunuh jamur yang bisa menyebabkan ketombe. Zinc pyrithione juga merupakan zat antibakteri. 2) Salicylic acid. Zat ini membantu melembutkan dan membuang kulit mati yang menumpuk pada kulit kepala. 3) Sampo berbahan ter. Bahan ter bisa membantu memperlambat produksi sel kulit mati. 4) Selenium sulfide. Zat ini berfungsi memperlambat produksi sel kulit mati dan membantu mengurangi pertumbuhan jamur. 5) Ketoconazole. Zat ini memiliki fungsi sebagai antijamur. Biasanya bahan ini digunakan jika bahan lain tidak memberikan hasil (Surani dan Putriana, 2017). Kegiatan penanganan kutu rambut dapat dilihat pada gambar 1.

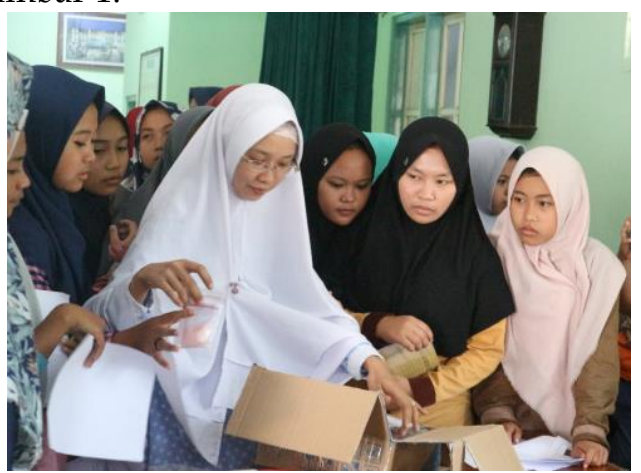

Gambar 1. Penanganan Kutu Rambut

\section{B. Pembuatan sampo antiketombe}

Untuk mengatasi masalah ketombe, pada sampo dapat ditambahkan bahan-bahan yang memiliki fungsifungsi antara lain: Comeocyte desquamating agents, keratin dissolution agents, antiseborrhoea agents, dan antibacterial agents. Hal-hal yang perlu diperhatikan dalam formulasi sampo meliputi: sampo harus memiliki kemampuan membersihkan yang cukup baik; harus dapat menghasilkan busa yang creamy, banyak, dan awet; harus mampu melindungi rambut akibat gesekan saat proses keramas; rambut harus memiliki kilau alami dan lembut setelah pencucian dengan sampo; serta harus aman terhadap rambut, kulit kepala, dan mata. Formula sampo mengandung foaming detergent dan beberapa bahan tambahan lainnya. Bahan tambahan lain yang biasanya terdapat dalam sampo antara lain: bahan berlemak, conditioning agent (polimer kationik), humektan, thickening agent, opacifying agent, pewarna, stabilizer, UV absorbent, pengawet, pengatur $\mathrm{pH}$. Beberapa bahan dapat 
ditambahkan untuk mengatasi ketombe dan gatal di kulit kepala seperti: triclocarban, sulfur, salicylic acid, zinc pyrithione (Z-pt), dan isopropyl methyl phenol (Mitsui 1998; Butler,2000).

Sampo yang dibuat oleh santri dapat langsung digunakan setelah selesainya kegiatan. Dalam pelatihan pembuatan sampo ini terdapat 20 orang santri yang mengikuti secara aktif dengan langsung melakukan praktek pembuatan sampo. Praktek dan diskusi berlangsung sangat menarik, karena santri tertarik dan ingin mengembangkan produksi sampo, tidak terbatas pada sampo salisilat tetapi juga sampo dengan komposisi bahan tambahan lain. Pada saat pelatihan ini juga diserahkan peralatan dan bahan yang diperlukan dalam pembuatan sampo. Kegiatan pelatihan pembuatan sampo antiketombe dan produk sampo antiketombe dapat dilihat masing-masing pada gambar 2 dan 3.

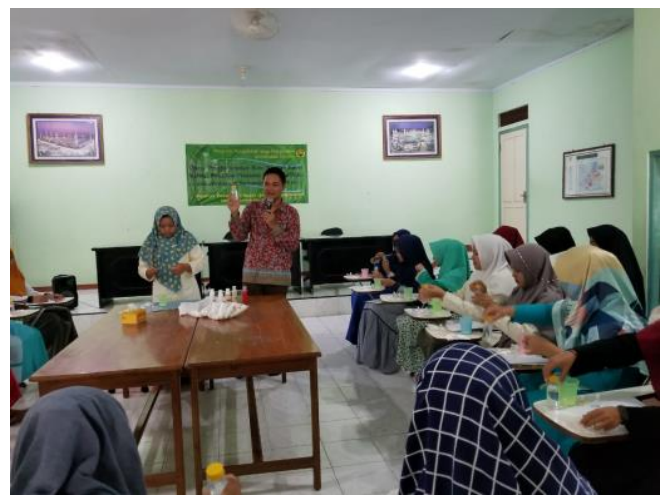

Gambar 2. Kegiatan Pelatihan Pembuatan Sampo Antiketombe

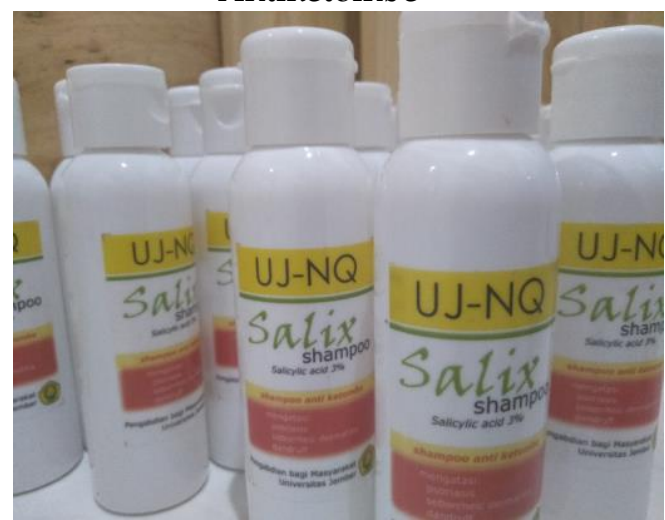

Gambar 3. Produk sampoo antiketombe

\section{Teknik mencukur rambut professional}

Pemangkasan rambut adalah suatu tindakan mengurangi ukuran panjang rambut semula yang dilakukan dengan Bauhear sisir, gunting dan jari-jari, guna memperindah atau mengubah bentuk pola pangkasan sebelumnya menjadi suatu mode tatanan rambut yang baru sesuai dengan perkembangan tren rambut saat itu dengan melihat kesesuaian bentuk wajah klien itu sendiri. Pemangkasan batang rambut yang seimbang, berstruktur, dan penguasaan teknik pola dasar dari pemangkasan rambut merupakan langkah awal yang harus dikuasai.Tujuan pemangkasan rambut adalah: untuk merubah bentuk tatanan rambut menjadi model rambut yang baru, untuk mendapat keindahan wajah dan penampilan baru, serta untuk memudahkan pengaturan dan penataan rambut. Kegiatan pelatihan pangkas rambut dapat dilihat pada gambar 4 .

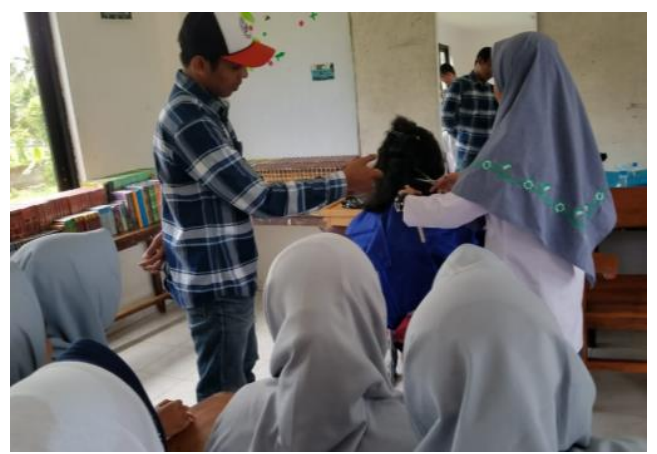

Gambar 2. Kegiatan Pelatihan Pangkas Rambut

\section{Simpulan}

Dari keseluruhan kegiatan pengabdian masyarakat yang terselenggara dapat disimpulkan bahwa tim pelaksana telah melakukan upaya untuk meningkatkan pengetahuan, kemandirian dan ketrampilan santri pondok pesantren Nurul Qarnain dalam mengatasi kutu rambut dan ketombe. Kegiatan yang dilakukan yaitu meliputi upaya kesehatan promotif melalui penyuluhan kesehatan, penanganan dengan pemberian paket obat, upaya pelatihan pembuatan sampo antiketombe dengan bahan aktif asam salisilat, dan upaya pelatihan pangkas rambut pada bulan Agustus-Nopember 2019.

Kegiatan Pengabdian ini perlu dilanjutkan untuk mencapai semua capaian luaran yang ditargetkan terutama untuk pelatihan pangkas rambut. Perlu dilaksanakan evaluasi terus-menerus terhadap keberlanjutan pelaksanaan kegiatan ini, sehingga pemberantasan kutu rambut dan ketombe maupun usaha pembuatan sampo tetap berjalan dan bisa menjadi upaya meningkatkan perekonomian pesantren. Kegiatan ini juga diharapkan dapat menjadi inisiasi dan percontohan untuk ponpes lain di Kabupaten Jember.

\section{Ucapan Terima Kasih}

Terima kasih diucapkan kepada Lembaga Penelitian dan Pengabdian kepada Masyarakat Universitas Jember atas dukungan dana dan fasilitas yang diberikan. Terima kasih juga diucapkan kepada pondok pesantren Nurul Qarnain Sukowono Jember atas kesempatan kejasama yang diberikan pada pelaksanaan kegiatan pengabdian. 


\section{Daftar Pustaka}

Alatas, Sahar, S.S., Linuwih, S. (2013). Hubungan Tingkat Pengetahuan Mengenai Pedikulosis Kapitis dengan Karakteristik Demografi Santri Pesantren X, Jakarta Timur. eJKI, Vol (1) 1:53-57.

Budi. (2019). Pesantren Nurul Qarnain Sukowono Jember. Retrieved Nopember 16, 2019 from https:// www.laduni.id/post/read/61217/pesantre n-nurul-qarnain-sukowono-jember.html

Butler, H. (2000). Poucher's Perfumes, Cosmetics and Soaps 10th Edition. London: Kluwer Academic Publishers

Haryono, Suryaningsih, I. B., Prasetyowati,I.(2016). Pembinaan Kewirausahaan Potong Rambut di Pesantren (Sebagai Upaya Meningkatkan Kemandirian Pesantren dan Santri. Retrieved Nopember 16, 2019 from http://repository.unej.ac.id/handle/123456789/73633.

Mitsui, T. (1998). New Cosmetic Science. New York: Elsevier

Polutri, Anusha, G., Haris, B., Pragathi, K.,\& Durraivel. (2013). Formulation and Evaluation of Herbal Antidandruff sampo. Indian Journal of Research in Pharmacy and Biotechnology, 1(6): 835-839.

Rassami W. \& Soonwera M. (2011). Effect of Herbal Sampo from Long Pepper Fruit Extract to Control Human HeadLouse of The Ladkrabang Childrens, Bangkok Thailand. Jurnal of Agricultural Technology, 7(2):331-338.

Surani F \& Putriana NA., (2017). Evaluasi Berbagai Sediaan Sampo Herbal Antiketombe dan Antikutu: Review Artikel. Farmaka, 15(2):218-232. 